\title{
Parametry badania echokardiograficznego pomocne w kwalifikacji do zabiegu MitraClip
}

\section{Echocardiographic parameters helpful in qualification for MitraClip surgery}

\author{
Monika Budnik \\ I Katedra i Klinika Kardiologii Warszawskiego Uniwersytetu Medycznego
}

\section{Streszczenie}

Obecnie najlepszą metodą leczenia niedomykalności zastawki mitralnej jest jej korekcja chirurgiczna (wymiana lub naprawa zastawki). Jednak z uwagi na często współistniejące inne choroby poszukiwane są alternatywne metody leczenia. Jedną z technik przezskórnego leczenia niedomykalności zastawki mitralnej jest poprawa koaptacji płatków przez zastosowanie systemu MitraClip.

Słowa kluczowe: MitraClip, niedomykalność mitralna, echokardiografia

Folia Cardiologica 2016; 11, 5: 487-490

Niedomykalność zastawki mitralnej (MR, mitral regurgitation) jest drugą pod względem częstości występowania wadą zastawkową wymagającą zabiegu chirurgicznego w Europie [1].

Wyróżnia się dwa typy MR - pierwotną i wtórną. Pierwotna (organiczna) MR obejmuje wszystkie przypadki z uszkodzeniem aparatu zastawkowego. Najczęściej występuje postać o etiologii zwyrodnieniowej, rzadziej przyczyną jest przebyta choroba reumatyczna lub infekcyjne zapalenie wsierdzia. Wtórna (czynnościowa) MR jest spowodowana zaburzeniem geometrii aparatu podzastawkowego wtórnego do poszerzenia i remodelingu lewej komory (LV, left ventricle). Jeżeli przyczyną wady jest choroba wieńcowa, to wtedy mówi się o niedokrwiennej MR. Kryteria rozpoznania ciężkiej MR według European Society Cardiology (ESC) przedstawiono w tabeli 1 [2].

Obecnie najlepszą metodą leczenia MR jest korekcja chirurgiczna (wymiana lub naprawa zastawki). Poszukiwane są jednak alternatywne metody, gdyż wielu pacjentów ma bardzo wysokie ryzyko operacyjne, głównie ze względu na wiek, upośledzenie funkcji lewej komory i choroby współistniejące. Jedną z technik przezskórnego leczenia niedomykalności zastawki mitralnej jest poprawa koaptacji płatków przez zastosowanie systemu MitraClip. Metoda ta naśladuje chirurgiczną technikę Alfieriego, polegającą na punktowym zespoleniu końców płatków w celu zbliżenia ich do siebie i zwiększenia koaptacji [3]. System MitraClip złożony jest z implantu składającego się z dwóch ramion, które mogą być otwierane i zamykane przy użyciu systemu wprowadzającego. Zastosowanie systemu jest możliwe zarówno w przypadku niedomykalności organicznej jak i czynnościowej. W przypadku niedomykalności organicznej MitraClip „zakotwicza” cepowaty lub prolapsowaty płatek zaś w przypadku niedomykalności czynnościowej poprawia koaptację płatków.

W badaniach klinicznych udowodniono skuteczność i bezpieczeństwo procedury. W badaniu EVEREST II (Endovascular Valve Edge-to-Edge REpair Study), w którym oceniano bezpieczeństwo i skuteczność zabiegu MitraClip, po 5 latach obserwacji okazało się, że pacjenci leczeni przezskórnie częściej wymagali leczenia operacyjnego, ale tylko w ciągu pierwszego roku po zabiegu. W analizie 
Tabela 1. Echokardiograficzne kryteria rozpoznania ciężkiej niedomykalności zastawki mitralnej (na podstawie [2])

\begin{tabular}{|c|c|}
\hline Metody & Opis \\
\hline \multicolumn{2}{|l|}{ Metody jakościowe } \\
\hline Morfologia zastawki & $\begin{array}{l}\text { Wiotki płatek/zerwany mięsień bro- } \\
\text { dawkowaty/duży defekt koaptacji }\end{array}$ \\
\hline $\begin{array}{l}\text { Fala zwrotna } \\
\text { niedomykalności }\end{array}$ & $\begin{array}{l}\text { Bardzo duży strumień centralny fali } \\
\text { zwrotnej lub ekscentryczny strumień } \\
\text { wywołujący zawirowania i osiągający } \\
\text { ścianę tylną lewego przedsionka }\end{array}$ \\
\hline $\begin{array}{l}\text { Wysycenie spektrum } \\
\mathrm{CW}\end{array}$ & Gęste/trójkątne \\
\hline Inne & Duża strefa konwergencji \\
\hline \multicolumn{2}{|l|}{ Metody półilościowe } \\
\hline $\begin{array}{l}\text { Szerokość talii fali } \\
\text { zwrotnej }[\mathrm{mm}]\end{array}$ & $\geq 7$ (> 8 głowicą dwupłaszczyznową) \\
\hline $\begin{array}{l}\text { Wsteczny przepływ } \\
\text { żylny }\end{array}$ & $\begin{array}{l}\text { Skurczowe odwrócenie przepływu } \\
\text { w żyłach płucnych }\end{array}$ \\
\hline Napływ & $\begin{array}{l}\text { Napływ mitralny } z \text { dominującą falą } E \geq \\
1,5 \mathrm{~m} / \mathrm{s}\end{array}$ \\
\hline Inne & TVI mitralne/TVI aortalne $>1,4$ \\
\hline \multicolumn{2}{|l|}{ Metody ilościowe } \\
\hline $\mathrm{EROA}\left[\mathrm{mm}^{2}\right]$ & Organiczna $\geq 40$ Czynnościowa $\geq 20$ \\
\hline RVol [ml/cykl] & Organiczna $\geq 60$ Czynnościowa $\geq 30$ \\
\hline $\begin{array}{l}\text { + Powiększenie jam } \\
\text { serca }\end{array}$ & Organiczna LV, LA \\
\hline
\end{tabular}

wieloczynnikowej wykazano, że wybór metody korekcji wady nie był związany z przeżywalnością [4]. W subanalizie obejmującej grupę pacjentów wysokiego ryzyka operacyjnego poważne zdarzenia niepożądane (MAE, major adverse events) występowały z częstością 18,8\% po 30 dniach i 37,6\% po 12 miesiącach. Po wyłączeniu konieczności przetaczania krwi częstość MAE zmalała do odpowiednio 9,1\% i 27,9\%. Zgony występowały z częstością z częstością 4,8\% w obserwacji 30-dniowej [5]. Szczegółowe dane zawarto w tabeli 2.

Ocenę skuteczności zabiegu MitraClip oraz śmiertelność pacjentów na podstawie dwóch największych badań klinicznych oraz rejestru przedstawiono w tabeli 3 [6].

Ocena echokardiograficzna kwalifikująca do leczenia przezskórnego obejmuje badanie przezklatkowe oraz przezprzełykowe [9]. Jeżeli jest to możliwe należy zastosować obrazowanie 3D w celu dokładniejszej oceny morfologii zastawki. Badanie przezprzełykowe, zwłaszcza trójwymiarowe ma wyższość nad badaniem przezklatkowym, szczególnie do oceny patologii przedniego płatka lub komisur,
Tabela 2. Częstość poważnych powikłań po 30 dniach i 12 miesiącach (na podstawie [5])

\begin{tabular}{|c|c|c|}
\hline \multirow{2}{*}{$\begin{array}{l}\text { Powikłanie } \\
(n=131)\end{array}$} & \multicolumn{2}{|c|}{ Częstość } \\
\hline & $30 \mathrm{dni}$ & $\begin{array}{l}12 \text { mie- } \\
\text { sięcy }\end{array}$ \\
\hline Zgon (\%) & 4,8 & 22,8 \\
\hline Zawał serca (\%) & 1,1 & 2,3 \\
\hline Nieplanowana operacja chirurgiczna (\%) & 0,3 & 0,3 \\
\hline Udar mózgu (\%) & 2,6 & 3,4 \\
\hline Niewydolność nerek (\%) & 1,7 & 5,4 \\
\hline Mechaniczna wentylacja > $48 \mathrm{~h}(\%)$ & 2,8 & 5,4 \\
\hline $\begin{array}{l}\text { Powikłania ze strony przewodu pokarmo- } \\
\text { wego wymagające leczenia chirurgicznego } \\
(\%)\end{array}$ & 0,3 & 1,4 \\
\hline $\begin{array}{l}\text { Początek utrwalonego migotania przed- } \\
\text { sionków (\%) }\end{array}$ & 0,3 & 0,3 \\
\hline Posocznica (\%) & 0,9 & 4,3 \\
\hline Konieczność przetoczenia > 2 j. krwi (\%) & 13,4 & 22,5 \\
\hline Łącznie (\%) & 18,8 & 37,6 \\
\hline $\begin{array}{l}\text { Łącznie (po wyłączeniu przetoczenia krwi } \\
>2 \text { j.) (\%) }\end{array}$ & 9,1 & 27,9 \\
\hline
\end{tabular}

rozpoznania perforacji płatka czy procesu infekcyjnego. Ma szczególne zastosowanie w celu potwierdzenia istotności niedomykalności, określenia jej mechanizmu oraz anatomicznych możliwości implantacji MitraClip. Należy pamiętać, że istotność czynnościowej niedomykalności może zostać niedoszacowana jeżeli badanie zostanie wykonane w znieczuleniu ogólnym [10]. Dlatego badanie echokardiograficzne do oceny niedomykalności zastawki mitralnej powinno być wykonywane w optymalnym stanie hemodynamicznym, przy prawidłowym ciśnieniu tętniczym i częstości rymu serca.

Kryteria, które determinują powodzenie zabiegu MitraClip zostały podzielone na optymalne, warunkowo odpowiednie i nieodpowiednie do przeprowadzenia skutecznego zabiegu $[11,12]$. Przedstawiono je w tabeli 4 [6].

Zaproponowano również kryteria, które powinno się zastosować do oceny stopnia niedomykalności mitralnej po zabiegu implantacji MitraClip (tab. 5) [6].

Przykład badania echokardiograficznego po zabiegu MitraClip przedstawiono na rycinie 1.

\section{Konflikt interesów}

Autorka deklaruje brak konfliktu interesów. 
Tabela 3. Wyniki badań dotyczących śmiertelności i skuteczności MitraClip (opracowano na podstawie [6])

\begin{tabular}{|c|c|c|c|c|c|}
\hline \multirow{2}{*}{$\begin{array}{l}\text { Nazwa badania/ } \\
\text { /rejestru }\end{array}$} & \multirow[t]{2}{*}{$n$} & \multicolumn{2}{|c|}{ Śmiertelność (\%) } & \multirow{2}{*}{$\begin{array}{c}\text { 1-roczne przeżycie bez } \\
\text { leczenia operacyjnego (\%) }\end{array}$} & \multirow[t]{2}{*}{ 1-roczne MR $\leq 2(\%)$} \\
\hline & & 30-dniowa & 1-roczna & & \\
\hline EVEREST II [5] & 351 & 4,8 & 22,8 & 97,8 & 84 \\
\hline ACCESS EU [7] & 567 & 3,4 & 17,3 & 93,7 & 79 \\
\hline TRAMI registry [8] & 1064 & 2,8 & - & - & - \\
\hline
\end{tabular}

Tabela 4. Cechy morfologiczne zastawki mitralnej kwalifikującej do implantacji MitraClip (opracowano na podstawie [6])

\begin{tabular}{|c|c|c|}
\hline Optymalna morfologia zastawki & Warunkowo odpowiednia morfologia zastawki & Nieoptymalna morfologia zastawki \\
\hline $\begin{array}{l}\text { Niedomykalność centralna } \\
\text { z segmentu A2 i/lub P2 }\end{array}$ & $\begin{array}{l}\text { Patologia w segmencie } 1 \text { lub } 3 \text { płatka tylnego } \\
\text { i przedniego }\end{array}$ & Perforacja płatka lub kleft \\
\hline Brak kalcyfikacji płatków & $\begin{array}{l}\text { Niewielkie kalcyfikacje poza obszarem uszko- } \\
\text { dzenia }\end{array}$ & Istotne kalcyfikacje w obszarze uszkodzenia \\
\hline MVA $>4 \mathrm{~cm}^{2}$ & MVA > $3 \mathrm{~cm}^{2}$ z dobrą ruchomością płatków & $\begin{array}{l}\text { Istotna hemodynamicznie stenoza mitralna } \\
\text { (MVA }<3 \mathrm{~cm}^{2} \text {, średni gradient }>5 \mathrm{~mm} \mathrm{Hg} \text { ) }\end{array}$ \\
\hline $\begin{array}{l}\text { Szerokość wypadającego } \\
\text { płatka } \leq 15 \mathrm{~mm} \\
\text { (pierwotna niedomykalność) }\end{array}$ & $\begin{array}{l}\text { Szerokość wypadającego płatka > } 15 \text { mm } \\
\text { w przypadku dużego pierścienia pozwalającego } \\
\text { na implantację kilku klipsów }\end{array}$ & $\begin{array}{l}\text { Zespół Barlowa z wypadaniem płatka w wie- } \\
\text { lu segmentach }\end{array}$ \\
\hline $\begin{array}{l}\text { Przerwa w koaptacji płatków < } 1 \text { mm } \\
\text { (pierwotna niedomykalność) }\end{array}$ & Głębokość koaptacji $\geq 11 \mathrm{~mm}$ & Przerwa pomiędzy płatkami > $2 \mathrm{~mm}$ \\
\hline $\begin{array}{l}\text { Głębokość koaptacji < } 11 \text { mm } \\
\text { (wtórna niedomykalność) }\end{array}$ & $\begin{array}{l}\text { Długość ruchomego tylnego płatka pomiędzy } \\
6-7 \mathrm{~mm} \text { a } 10 \mathrm{~mm}\end{array}$ & $\begin{array}{l}\text { Niewystarczająca długość ruchomego tylne- } \\
\text { go płatka }\end{array}$ \\
\hline $\begin{array}{l}\text { Długość koaptacji } \geq 2 \text { mm } \\
\text { (niedomykalność czynnościowa) }\end{array}$ & Restrykcja skurczowa płatków (Carpentier IIIB) & $\begin{array}{l}\text { Reumatyczne pogrubienie i restrykcja } \\
\text { w skurczu i rozkurczu (Carpentier IIIA) lub } \\
\text { uszkodzenie zastawki w wyniku zapalenia } \\
\text { wsierdzia }\end{array}$ \\
\hline \multicolumn{3}{|l|}{$\begin{array}{l}\text { Długość ruchomego tylnego płatka } \\
\geq 10 \mathrm{~mm}\end{array}$} \\
\hline $\begin{array}{l}\text { Prawidłowe napięcie i ruchomość } \\
\text { płatków }\end{array}$ & & \\
\hline
\end{tabular}

Tabela 5. Echokardiograficzne parametry oceny stopnia niedomykalności po zabiegu implantacji MitraClip (opracowano na podstawie [6])

\begin{tabular}{|c|c|}
\hline $\begin{array}{l}\text { Parametry echokardiograficzne do oceny stopnia nie- } \\
\text { domykalności mitralnej po implantacji MitraClip }\end{array}$ & Parametry świadczące o efektywności zabiegu \\
\hline $\begin{array}{l}\text { Pole powierzchni strumienia fali zwrotnej ocenianej } \\
\text { metodą kolorowego doplera }\left[\mathrm{cm}^{2}\right]\end{array}$ & $\begin{array}{l}\text { Pole powierzchni }<10 \mathrm{~cm}^{2} \text { i stosunek }<40 \% \text { do pola powierzchni LA świad- } \\
\text { czą o nieistotnej niedomykalności }\end{array}$ \\
\hline Przepływ wsteczny w żyłach płucnych & Istotna redukcja MR powoduje zanik odwrócenia przepływu w żyłach płucnych \\
\hline Talia fali zwrotnej [mm] & $<7$ mm świadczy o nieistotnej MR \\
\hline 2D PISA EROA $\left[\mathrm{mm}^{2}\right]$ & $\begin{array}{l}\text { ERO }<20 \mathrm{~mm}^{2}=\text { mała MR } \\
20-39 \mathrm{~mm}^{2}=\text { umiarkowana MR } \\
\geq 40 \mathrm{~mm}^{2}=\text { ciężka niedomykalność }\end{array}$ \\
\hline Objętość fali zwrotnej [ml] & $\begin{array}{l}\text { MR vol } \geq 60 \mathrm{ml}=\text { duża niedomykalność } \\
30-59=\text { umiarkowana niedomykalność } \\
<30 \mathrm{ml}=\text { mała niedomykalność }\end{array}$ \\
\hline 3D ROA & $<41 \mathrm{~mm}^{2}$ świadczy o nieistotnej niedomykalności \\
\hline
\end{tabular}

LA (left atrial) - lewy przedsionek; 2D (2-dimensional) - dwuwymiarowe; MR (mitral regurgitation) - niedomykalność zastawki mitralnej; PISA (proximal isovelocity surface area) pole strefy konwergencji przepływu; EROA (effective regurgitant orifice area) - efektywne pole ujścia fali zwrotnej; ROA (regurgitant orifice area) - pole ujścia fali zwrotnej; vol (volume) - objętość; 3D (3-dimensional) - trójwymiarowe 


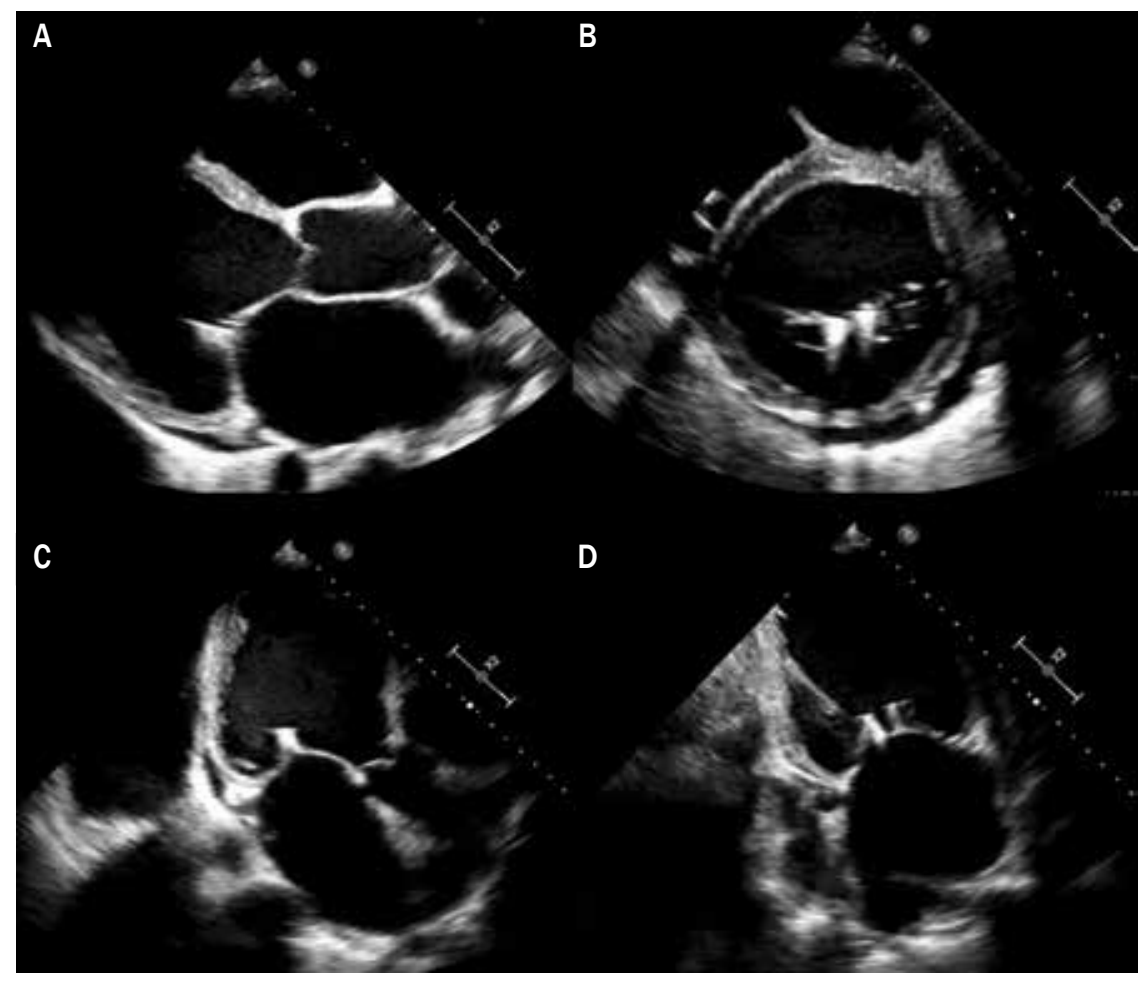

Rycina 1A-D. Badanie echokardiograficzne pacjenta po zabiegu implantacji MitraClip (materiał z I Katedry i Kliniki Kardiologii Warszawskiego Uniwersytetu Medycznego)

\section{Abstract}

Currently, the best method of treatment of mitral regurgitation is the surgical correction (valve repair or replacement). However, because of the coexisting comorbidities alternative therapies are sought. One technique for percutaneous treatment of mitral regurgitation is applying the MitraClip system.

Key words: MitraClip, mitral regurgitation, echocardiography

Folia Cardiologica 2016; 11, 5: 487-490

\section{Piśmiennictwo}

1. lung B., Baron G., Butchart E.G. i wsp. A prospective survey of patients with valvular heart disease in Europe: the Euro Heart Survey on Valvular Heart Disease. Eur. Heart J. 2003; 24: 1231-1243.

2. The Joint Task Force on the Management of Valvular Heart Disease of the European Society of Cardiology (ESC) and the European Association for Cardio-Thoracic Surgery (EACTS). Guidelines on the management of valvular heart disease (version 2012). Eur. Heart J. 2012; 33: 2451-2496.

3. De Bonis M., Lapenna E., La Canna G. i wsp. Mitral valve repair for functional mitral regurgitation in end-stage dilated cardiomyop- athy: role of the "edge-to-edge" technique. Circulation 2005; 112 (supl. 9): 1402-1408.

4. Feldman T., Kar S., Elmariah S. i wsp. randomized comparison of percutaneous repair and surgery for mitral regurgitation: 5 -year results of EVEREST II. J. Am. Coll. Cardiol. 2015; 66: 2844-2854.

5. Glower D.D., Kar S., Trento A. i wsp. Percutaneous mitral valve repair for mitral regurgitation in high-risk patients: results of the EVEREST II study. J. Am. Coll. Cardiol. 2014; 64: 172-181.

6. Zamorano J., Gonçalves A., Lancellotti P. i wsp.; EACVI Reviewers. The use of imaging in new transcatheter interventions: an EACVI review paper. Eur. Heart J. Cardiovasc. Imaging 2016; 17: 835-835.
7. Maisano F., Franzen 0., Baldus S. i wsp. Percutan- eous mitral valve interventions in the real world: early and 1-year results from the ACCESS-EU, a prospective, multicenter, nonrandomized post-approval study of the MitraClip therapy in Europe. J. Am. Coll. Cardiol. 2013; 62: 1052-1061.

8. Schillinger W., Hunlich M., Baldus S. i wsp. Acute out- comes after MitraClip therapy in highly aged patients: results from the German TRAns-catheter Mitral valve Interventions (TRAMI) Registry. Eurolntervention 2013; 9: 84-90.

9. O'Gara P., Sugeng L., Lang R. i wsp. The role of imaging in chronic degenerative mitral regurgitation. JACC Cardiovasc. Imaging 2008; 1: 221-237.

10. Boekstegers P., Hausleiter J., Baldus S. i wsp. Percutaneous interventional mitral regurgitation treatment using the Mitra-Clip system. Clin. Res. Cardiol. 2014; 103: 85-96.

11. Willson A.B., Rodes-Cabau J., Wood D.A. i wsp. Transcatheter aortic valve replacement with the St. Jude Medical Portico valve: first-in-human experience. J. Am. Coll. Cardiol. 2012; 60: 581-586.

12. Herrmann H.C., Kar S., Siegel R. i wsp. Effect of percutaneous mitral repair with the MitraClip device on mitral valve area and gradient. Eurolntervention 2009; 4: 437-442. 